\title{
Lex Superior Versus Lex Inferior: Selection Between Social Norms and Applicable Legal Norms
}

\author{
${ }^{1}$ Saifullah Bombang, ${ }^{2}$ Syamsul Haling, ${ }^{3}$ Paisal Halim \\ ${ }^{1}$ Sekolah Tinggi Agama Islam Palu, Central Sulawesi, Indonesia \\ ${ }^{2}$ Universitas Muhammadiyah Palu, Central Sulawesi, Indonesia \\ ${ }^{3}$ Universitas Nasional, Jakarta, Indonesia \\ Email:saifullah.bombang@gmail,syamsul.halingpalu@gmail.com,paisalhalim@gmail.com
}

Received: 10 $^{\text {th }}$ July 2019, Accepted: 30 ${ }^{\text {th }}$ July 2019, Published: $31^{\text {st }}$ August 2019

\begin{abstract}
Human life cannot separate from social norms that become a benchmark for behavior. Social norms have validity and power applicable to legal subjects. In addition to human social norms, it is also bound by legal norms, which also have validity and power applicable to legal subjects. Types of research methods used are normative legal research focusing on positive legal norms in the form of legislation, namely by reviewing the laws and regulations governing the registration of arbitration decisions to realize legal certainty for the parties while empirically is to see the reality directly occur in the field. In such situations, it will be able to arrive at one meeting point, namely social norms with legal norms in the same position. The choice of personal priority will take only one norm in this paper called Lex superior versus Lex inferior. Norms with a superior Lex position will face with inferior Lex norms, which in turn are only one social norm that will fulfill both in the position of superior Lex and inferior Lex. Humans only choose one social norm that believed and expected to fulfill their interests and demands (material and spiritual). Consequently, logically from this position, humans will be trapped in the struggle of the superior Lex norm with Lex inferior in a continuous and alternating manner throughout their lives. Inharmonious and disharmonic interactions, often people trapped in a pattern of logical relationships that are diverse and alternating both constructive, contrarian, and sub-alternative.
\end{abstract}

\section{Keywords}

Norms Social, Lex Superior, Lex Inferior, Behavior, Legal Subject

\section{Introduction}

In the level of the formation of legislation known as the sound level theory (Stufentheorie) proposed by Hans Kelsen [1]. In the theory Hans Kelsen argues that legal norms are hierarchical and layered in a hierarchy (arrangement) in the sense that a higher norm is valid, sourced and based on higher norms, and so on until a norm that cannot be traced further and are hypothetical and fictitious, namely Basic Norms (Grundnorm) [2]. Basic norms are the highest norms in a norm system that are no longer formed by a higher norm, but the basic norms are determined beforehand by the community as a fundamental norm which is a hanger for the norms below it so that a basic norm said to be pre-supposed [3].

Legal norms always sourced and based on the norms above, but below the legal norms are also a source and become the basis for norms that are lower than that [3]. In terms of the arrangement/hierarchy of the norm system, the highest norm (Basic Norm) becomes the place where the norms underneath depend on it, so that if the Basic Norms change it will be a breakdown of the norm system underneath [4]. Hans Nawiasky said that a legal norm from any country is always layered and tiered [5]. The below norms apply, sourced, and based on higher norms, higher norms apply, sourced, and based on the highest norms called Basic Norms [6].

Human life has many social norms that are a means of achieving goals or human dreams. This view is also expressed by Eric A. Posner [7], that in the order of life, there are social norms and legal norms. These social norms become a means for humans to interact and become a barrier between human behavior in social life. Social norms are general habits that become a benchmark of behavior in a group of people and certain regional boundaries [8]. Norms will develop along with the social agreements of the people, often also referred to as social regulations. The functions of social norms in the community are: (1) as guidelines and rules in community life (2) creating order and stability in society (3) as a basis in giving sanctions to community members who violate and (4) creating involvement and justice in society, and (5) assisting the community in achieving common goals. Norms are all living instructions that regulate the order in a society or nation where the regulation is obliged to be obeyed by every society, if there is a violation then there will be action from the government [9]. In Eric A. Posner's view that what is the role of law in a society that is maintained is mostly through social norms, trusts, and non-legal sanctions. This view shows how significant the role of social norms is in achieving public order. It can even state that the role of law diminished after the existence of social norms [10].

Social norms are norms that exist in society, and there are various forms of norms. These norms depend on two aspects of human life, namely aspects of personal life and aspects of interpersonal life. The social order that exists in society realized thanks to the prevailing guidelines because of the diversity of norms that lived out by the community. Besides, this is also due to statutory laws that cannot regulate all aspects of human life [11]. The establishment of legal norms originates from these social norms, and some are due to the needs of human life that require legal rules. The process of changing social norms into legal norms begins with the need for a guideline to achieve the goal of living together. In the context of human 
beings as social beings, the purpose of living together to achieve is peace and regularity of life between humans [12]. To achieve this common goal, a guideline needed that regulates how humans can behave appropriately and adequately in society. This process of change can also attribute to humans as social beings. As social beings, humans given the ability to think to run their lives. Humans also need basic needs that must meet. The fulfillment of this need cannot do it immediately. In meeting these needs a rule or guideline needed as a norm [13].

The social norms found in society can be moral norms, religious norms, legal norms, customary norms, cultural norms [14]. These social norms have a variety of validity and enforceability and characteristics so that in managing human life in society, the degree of its effectiveness also varies [15,16]. Among these social norms, legal norms have a dominant place (more being Lex superior) in managing human activities than social norms other than legal norms, because they are enforced and maintained by a legitimate governmental power so that the validity and enforcement are more dominant [17]. The dominance of legal norms rather than social norms makes legal norms qualify as Lex superior in general cases (public binding, e.g., criminal law and state administration) because they receive support from the government and social norms become inferior Lex, especially in cases which meets legal norms) [18]. In this regard, in this introductory chapter, legal issues were proposed, why did they occur between legal norms as superior Lex, facing the social norm as inferior Lex or vice versa. Which argument supports that legal norms in managing human life in society obtain a dominant position (Lex superior) from social norms (Lex inferior). Besides, further problems at the time when social norms qualify as Lex superior and at the time when legal norms become inferior Lex or vice versa will be stated in the subject matter of the discussion. Some of these issues are interesting to analyze so that this paper becomes feasible to become a legal, scientific paper.

\section{Research Methods}

Research Approach: The approach is taken in this study divided into two types of approaches as follows:

- A normative juridical approach is an approach carried out based on the primary legal material by examining theories, concepts, legal principles, and laws and regulations related to this research. This approach is also known as the library approach, namely by studying books, legislation, and other documents related to this research [19].

- An empirical juridical approach that carried out by looking at the reality in practice in the field. This approach is also known as the sociological approach that carried out directly to the field.

Data Collection: The method of data collection in this study was carried out by a literature study, namely a method of collecting data by searching and analyzing library materials (literature, research results, scientific magazines, scientific bulletins, scientific journals). In, the primary source is legal material that is associated with social facts because, in the study of empirical legal studies, it is not only legal material but also the opinions of experts [20].

Data Analysis: To analyze the data obtained, it will use the normative analysis method, is a way of interpreting and discussing the results of research based on the notions of law, legal norms, legal theories and doctrines related to the subject matter. Legal norms needed as a major premise, then correlated with relevant facts (legal facts) which are used as minor premises and through a syllogism process, conclusions will obtain for the problem [21]. The results of the study are presented in the form of systematically structured descriptions, meaning that the secondary data obtained will be connected according to the problem under study, so that overall it is a unified whole following the needs of the study.

\section{Result and Discussions}

Some cases of court decisions that show descriptions of social norms are in a position that is not superior (first), first, the decision of the criminal court of the Sangraha Logic case (Indigenous moral offense of Bali), the judge uses customary law norms as the basis of the decision (Lex superior). For example, the decision of the Supreme Court of the Republic of Indonesia in 2013, which overturned the judgment of the judicial facti court, namely the Klungkung District Criminal Court and the Bali High Criminal Court against the case of the Balinese Custom Delict. This decision indicates that the position of customary social norms of adoption is a legal norm that overrides the moral norms of law stipulated in Article 281 of the Civil Code concerning decency offenses. Second, the Civil Court Decision, overriding the norms of the Civil Code by customary legal norms applied by the Makassar state justice that reduces and excludes legal norms in the Civil Code Article 1338 which applies the concept of profit sharing according to customary law. Third, the decision of the Medan High Court to adopt the Batak Customary social norm (Lex superior) regarding the dispute, which regulates that according to the Batak custom if both parents die all inheritance left before shared by their heirs usually controlled by the oldest child of the deceased parent.

Social change in society is a necessity. Change is natural, which is a logical consequence of the growth that occurs in society continuously. Social change also marks a shift in values and norms in society, resulting in a conflict of values and norm conflict, which is also a necessity. Theoretically, society is a collection of individuals and groups that interact simultaneously, so that, at any time, space and time change behavior, both individuals and groups in society. Although there are changes and shifts in social values and norms alternately in the processes of social interaction, and social norms surround society. Social norms in society can be legal norms (laws), customary norms, custom norms, religious norms, politeness norms, and moral norms. Descriptions of social norms that bind the community in activities appear in the following picture: 


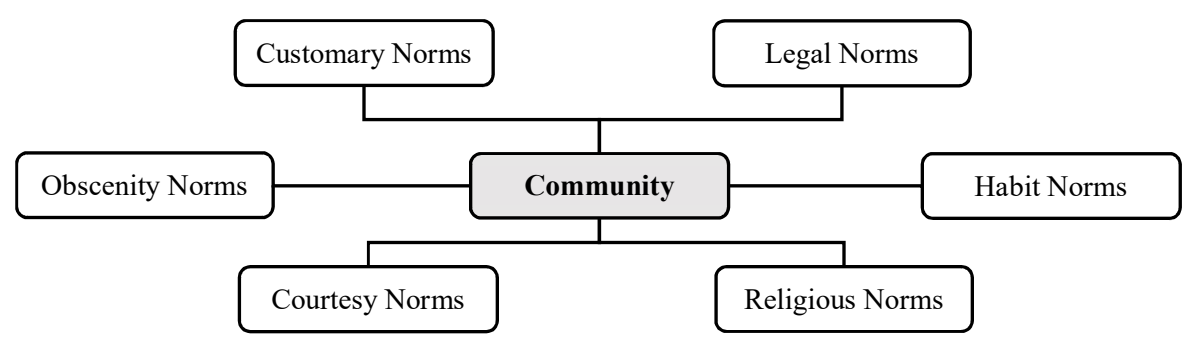

Figure 1: Social Norms That Bind the Community

Linkages Social Norms with Legal Norms: In every society, both traditional and modern society, there are social norms as a reference for each or group to interact. Social interaction in the community indicates the existence of different interests from each other community members and different interests intended to be the driving force of social interaction. The functions of social norms, including legal norms in social interaction, become guides to fulfill these different interests. The social norms and legal norms are meant to carry out social functions, namely, to maintain orderliness and continuous interaction between individuals and groups in an orderly manner [22]. In fact, in addition to this, social norms also carry out the task of pursuing two vital interests of humanity, namely (bi-singular), namely the value of spiritual interest (spiritualism) and the value of physical or material interests (materialism). Besides, it also pursues the value of novelty (innovation) and the value of permanence (conservatism).

The existence of social norms and legal norms both have the same object, namely human behavior. Humans as the target of the implementation of norms are all subject to the prevailing norms to achieve the dual purpose. Regarding the topic of discussion and issue issues, it is known that between social norms and legal norms, there is a position that sometimes overlaps each other in the sense of complementary, which guides human behavior [23]. Also, these two social norms sometimes overlap certain behaviors. Specific actions that complement and strengthen each other when the norms regulate the same thing, such as the obligation to respect others (the rights of others) and the same obligations while overlapping and impressing antinomy when dealing with social norms regulates human relations with God [24]. The relationship in practice must have chosen (chosen) or prioritized, which in this paper positioned as Lex superior (religious norm) while the others positioned as inferior Lex. Nevertheless, humans sometimes fall into an ambiguous position (confusion) to choose which norms should be superior Lex and which norms positioned as inferior Lex.

Disharmony of Social Norms with Legal Norms: In certain positions, social norms with legal norms are in a disharmony position. Disharmony occurs because legal norms also regulate objects regulated by social norms. The similarity of the object occurs because social norms and legal norms govern the same interests and goals of legal subjects. In such conditions, the subject of law will choose norms that are following the interests and objectives desired. The legal subject will occur where the choice of norms (choice of law) chosen and prioritized so that social norms can be superior and legal norms as inferior Lex or vice versa.

Antinomy Social Norms with Legal Norms: Antinomy in law is something that cannot deny. Antinomy is the occurrence of different relationships between social norms and legal norms found in society. Theoretically, antinomy is a condition where the emergence of a new norm that grows because of the development of science and technology and the demands of society. Its development triggered by social changes that necessitated social norms (including legal norms) to enter the antinomy phase. Other norms shift changes in the values and norms of old norms in turn.

Social norms and legal norms theoretically have the same sources and values and principles, namely, the value of necessity, and universally applicable principles, such as the principle of equality, principles of responsibility [25]. The application of these social norms by legal subjects faced with choices in behaving to cause antinomy. Antinomy from the source of value to social norms, namely the existence of new behaviors that grow accompanied by the norms of things where new values or norms do not know the community before [26].

The emergence of new values and norms causes the old values and norms to be valid (transition) so that a process of shifting values and norms in the community takes place slowly [27]. In this condition, both social norms and legal norms will lose their applicability slowly so that in society, there are several social norms and legal norms to become superior Lex, and others become inferior Lex. The enactment of established social norms and legal norms will shake to face the social conditions that surrounded by the forerunner of new norms so that there can be a new norm that becomes superior Lex and some become Lex inferior. Concerning the topic of this writing, it appears that the emergence of antinomy social norms in the form of norm superiority (high and low) in social interactions because of the choice of legal subjects (choice of law) following their wants and needs. The choice of social norms for legal subjects is not only on social norms that are facultative but also on social norms that are imperative (coercive). Therefore, if analyzed in social interaction in society there will always be superiority between social norms and which norms are superior and which social norms are inferior to the extent to which social norms support ideals, goals and demand legal subject. There are many possibilities for the occurrence of Lex superior versus Lex inferior in all fields of social interaction in society. 
Pattern - Logis Lex Superior Relationship Pattern and Lex Inferior: In social interaction in society, some patterns and structures for the condition of superiority will form (Lex superior versus Lex inferior) as its form. Namely, the first pattern is a compromise pattern. This pattern meets two interests in regulating legal subjects with compelling character. This pattern is related to the existence of meeting points of regulation of interests between social norms and legal norms which contain external coercion elements. It can happen, this pattern describes the regulation of the importance of religious norms (zakat, for example) with tax legal norms (taxpayers). Both displaying behavioral norms that have a command character (god) that choose legal subjects and legal subjects can only implement both without ignoring one of them, namely paying taxes and paying zakat. The second pattern is the different patterns of legal subjects, choosing one of them. Usually, for adherents of strong religion, they will ignore paying taxes (state orders) and oblige themselves to pay zakat (religious orders) and this position shows that Lex superior is religious norms and Lex inferior is the legal norm. The third pattern, the sub-contrary pattern is the pattern in which legal subjects ignore both imperative norms (orders) by using emergency reasons by using norms of permission or dispensation to the authorities whose norms derived from both social norms and religious norms. So, the Lex superior is the norm of permission and dispensation, and the Lex inferior is the norm of order which is generally required both from the social norms and legal norms. The fourth pattern is the "false contrast" pattern, which is the pattern of implementing social norms where the implementation is on two possible sides, namely, on the one hand carrying out norms of conduct in the form of licenses which initially ordered and on the other hand dispensation (possibility) which was initially a prohibition for him. The fifth pattern, the sub-alternation pattern, which is the pattern of the implementation of norms - social norms where the legal subject performs a general obligation (pioneer and prohibition) and can also carry out social norms specifically (particulars) as special permission the same quality (doing something or not doing something). When the legal subject chooses behavior that contains social norms of unique ability, then the social norms of special functions become Lex superior, and the general order becomes Lex inferior. The fourth pattern is, the pattern of contradictions, namely there are social norms that are ordered or prohibited, and also there are permits and dispensations, then the subject of law only chooses one of the social norms. The choice of which social norms are chosen and carried out by legal subjects, then the choice of social norms for legal subjects becomes superior, and the other social norms not elected as Lex inferior [28]. The following figure shows the implementation of patterns of superiority and inferiority in social norms in the structure of behavioral law norms:

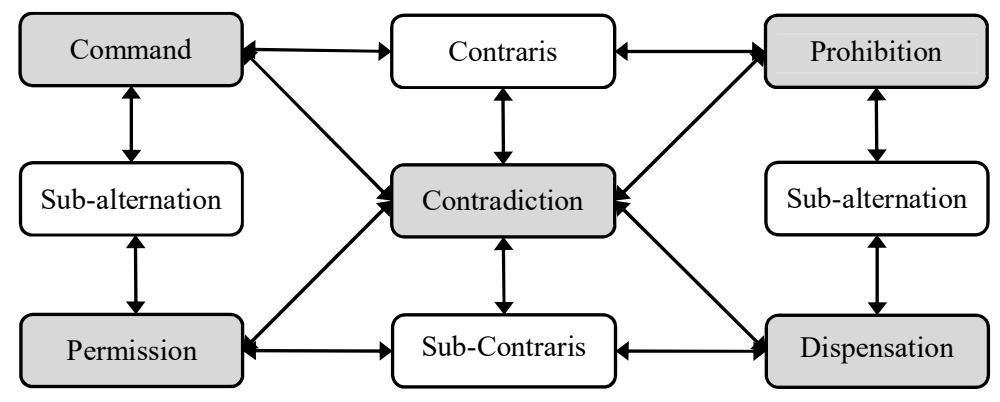

Figure 2: Logical Relationship Patterns of Lex Superior and Lex Inferior

Based on the patterns of logical relations, in social interactions within the community, there will be repeated patterns of logical relations which indicate the existence of the Lex superior and Lex inferior phenomena. The transition from one pattern to another pattern is a choice of legal subject with all the risks and legal consequences of both consequences related to positive law and consequence on the morality of legal subjects. The choice of relationship patterns is the full form of interests and needs and demands of each or group.

In the implementation of mutually agreed norms, if there is a violation of a social norm, there will be social sanctions. If a sanction enforces social norms, then the norm becomes a legal norm. Differences in legal norms and social norms are legal norms that can apply the use of force that exists in organized communities to avoid or punish violations of social norms. In social life, many social norms must be obeyed. This norm is a rule that contains guidelines about how behavior is considered socially acceptable [29]. If someone violates certain social norms, there will be social sanctions such as being ostracized, ridiculed, and so on. However, over time, among these social norms, something is compelling, where if someone violates these norms, they will get strict sanctions in the form of punishment [30,31]. That is when social norms turn into legal norms.

Legal norms are also the result of multiple institutionalization processes that apply in society. The first institutionalization is the values that exist in people's lives institutionalized as social norms when those values adhered to, and there are social sanctions if they violate these values [32]. Then, the other institutionalization occurs when some of these social norms gradually forced. After these values through the other institutionalization, these values experience changes from social norms whose rules are uncertain and the sanctions are not clear to become legal norms that have definite rules and strict sanctions for violators of the norm $[33,34]$. 
For example, when there was no Law Number 44 of 2008 concerning pornography, someone who is considered to have committed acts that violate moral values and can arouse sexual desire cannot be prosecuted because there are no definite and written rules. However, after there is a law on pornography, a person cannot just take actions that are considered to violate the values of morality because they can be subject to strict sanctions following the applicable law.

The process of changing social norms becomes a legal norm because it requires a guideline to regulate human behavior and behave appropriately and adequately in society. The process of change can also be attributed to humans as social beings [35]. Humans need basic needs that must meet. In meeting these needs, guidelines needed so that the fulfillment of needs does not necessarily happen so that rules and norms are needed. Legal definitions depend on aspects, and scope of the broad scope [36]. The purpose of the law is to create peace and peace in the community. The function of law is as a means of social control to maintain the existing pattern of order or life [37,38].

\section{Conclusions}

Social norms in society are norms that can be chosen by individuals and groups in interacting with each other. Social norms carry out social functions as a benchmark for behavior, and their implementation varies according to the objectives, interests, and expectations of legal subjects. Legal subjects in the act of being able to choose between social norms as a reference for behavior (orders, prohibitions, permits, and dispensations) and the selection of social norms referred to will show a picture of social norms which positioned as Lex superior and Lex inferior. The selection also shows the existence of patterns of normative logical relationships that are illustrated abstractly in social interactions.

\section{References}

1. Kelsen H. General theory of norms. 1990;

2. Kelsen H. On the basic norm. Calif L Rev. 1959;47:107.

3. Hughes G. Validity and the basic norm. Calif L Rev. 1971;59:695.

4. Kelsen H. General theory of law and state. Routledge; 2017.

5. Nawiasky H. Allgemeine Rechtslehre als System der rechtlichen Grundbegriffe. Benziger; 1941.

6. Kelsen H. Principles of international law. The Lawbook Exchange, Ltd.; 2003.

7. Posner EA. Law and social norms. Harvard university press; 2009.

8. Hofstede G. Culture's consequences: Comparing values, behaviors, institutions and organizations across nations. Sage publications; 2001.

9. Nonet P. Law and society in transition: Toward responsive law. Routledge; 2017.

10. Posner EA. Law and social norms: The case of tax compliance. Va L Rev. 2000;86:1781.

11. Fuller LL. Human interaction and the law. Am J Juris. 1969;14:1.

12. Tonnies F, Loomis CP. Community and society. Routledge; 2017.

13. Epstein RA. The Social Consequences of Common Law Rules. Harv Law Rev. 1982;1717-51.

14. Curran PD. Universalism, Relativism, and Private Enforcement of Customary International Law. Chi J Int'l L. 2004;5:311.

15. Eisenberg MA. Corporate law and social norms. Colum L Rev. 1999;99:1253.

16. Hechter M, Opp K-D. Social norms. Russell Sage Foundation; 2001.

17. Habermas J. Between facts and norms: Contributions to a discourse theory of law and democracy. John Wiley \& Sons; 2015.

18. Slaughter A-M. International law in a world of liberal states. Eur J Int Law. 1995;6(3):503-38.

19. Hammer LM. A Foucauldian approach to international law: Descriptive thoughts for normative issues. Routledge; 2016.

20. Webley L. Qualitative approaches to empirical legal research. Oxford Handb Empir Leg Res. 2010;926-50.

21. Barkan SM, Bintliff B, Whisner M. Fundamentals of legal research. 2015;

22. Gouldner AW. The norm of reciprocity: A preliminary statement. Am Sociol Rev. 1960;161-78.

23. Gangemi A, Sagri M-T, Tiscornia D. A constructive framework for legal ontologies. In: Law and the semantic web. Springer; 2005. p. 97-124.

24. Rabinow P. French modern: Norms and forms of the social environment. University of Chicago Press; 1995.

25. Werle G, Jessberger F. Principles of international criminal law. OUP Oxford; 2014.

26. Krygier M. Law as tradition. Law Philos. 1986;5(2):237-62.

27. Ewald F. Norms, discipline, and the law. Representations. 1990;30:138-61.

28. McAdams RH, Rasmusen EB. Norms and the Law. Handb law Econ. 2007;2:1573-618.

29. Lempert R. Norm-making in social exchange: A contract law model. Law Soc'y Rev. 1972;7:1.

30. Lerner MJ. The justice motive in social behavior: Introduction. J Soc Issues. 1975;31(3):1-19.

31. Bicchieri C. The grammar of society: The nature and dynamics of social norms. Cambridge University Press; 2005.

32. Scott RE. The limits of behavioral theories of law and social norms. Va L Rev. 2000;86:1603.

33. Meyer JW, Rowan B. Institutionalized organizations: Formal structure as myth and ceremony. Am J Sociol. 1977;83(2):340-63.

34. Beckert J. Agency, entrepreneurs, and institutional change. The role of strategic choice and institutionalized practices 
in organizations. Organ Stud. 1999;20(5):777-99.

35. Hogg MA, Terry DI. Social identity and self-categorization processes in organizational contexts. Acad Manag Rev. 2000;25(1):121-40.

36. Teubner G. Substantive and refLexive elements in modern law. Law Soc Rev. 1983;239-85.

37. Grasmick HG, Green DE. Legal punishment, social disapproval and internalization as inhibitors of illegal behavior. J Crim L Criminol. 1980;71:325.

38. Cooter RD. Three effects of social norms on law: expression, deterrence, and internalization. Or L Rev. 2000;79:1. 